\title{
The Methodist Home Mission Party, On Stage in New Zealand, 1924-1934
}

\author{
MICHELLE WALKER
}

Choirs were a key component of entertainment in late nineteenth- and early twentieth-century New Zealand. Choirs have for the most part been understudied as a topic of both musical and historical investigation. One such choir, the Methodist Home Mission Party (MHMP) established in 1924 by Reverend Arthur John Seamer, consisted of indigenous Maori singers and orators who performed an eclectic range of repertoire, which included religious, indigenous, popular (mainstream) music and Western art music. This choral group sang and performed on many stages for nearly 12 months of each year from 1924 to 1938 . This article focuses on their extensive tours of New Zealand between 1924 and 1934 and thereby reveals an important aspect of New Zealand performance history, and more specifically its music history. At a time when live performance was sought after in communities throughout the country for entertainment, the MHMP had the ability to surprise, educate and enthral their audiences.

The stage, understood as "a space where different cultures and communities intersect, interact and are mutually influenced by the encounter," was crucial to the MHMP. The stage is a site that is constantly modified by performers in response to changing contexts, such as commercial or non-profit agendas, or religious environments compared to secular ones. ${ }^{2}$ By investigating the MHMP and the various repertoire they performed, I cast light on the diversity of both Māori and European musical traditions extant on the New Zealand stage, including a vibrant cross-cultural performance culture. Each performance enabled education as well as development for not only the performers involved, but also their audiences throughout New Zealand and later in Australia and Great Britain. ${ }^{3}$

\section{Formation of the Methodist Home Mission Party}

The figurehead and director of the Methodist Home Mission Party was Reverend Arthur John Seamer (1878-1963), an Australian-born Methodist minister. Seamer immigrated to New Zealand in 1897 as a Salvation Army missionary recruit; ${ }^{4}$ however, he served his 38-year ministerial career within the Methodist fold. ${ }^{5}$ When he began working for the New Zealand Methodist Church in 1901, the church structure was organized in a nationwide circuit system. The North Island was divided into five Mission districts, each of which was assigned a Home Mission Superintendent as well as a Native (Māori) Superintendent, while the South Island mission circuit was left intact for several ministers to operate. ${ }^{6}$ The Home Mission and Maori Mission were two parts of the Methodist Church's evangelical branch, with the Home Mission relating specifically to the Pākehā process of evangelism. The church used these departments to actively recruit and maintain Methodist congregations. One General Superintendent, T.G. Hammond, was designated to supervise the Maori Mission Department until 1920. One General Superintendent also oversaw the European (Home) Mission Department, which was managed from 1915 to 1924 by Reverend T.G. Brooke. ${ }^{7}$ The declared aim of both the Home and Maori Mission Departments was to foster the integration of Māori and Europeans into the church. ${ }^{8}$

Seamer rose rapidly within the Methodist ranks and by the 1920s was especially well regarded by his peers and congregations for his work among Māori communities. This work was acknowledged in 1920 with his appointment to General Superintendent of the Maori 
Mission, a role which involved constant travel between the various Māori congregations and communities. Seamer was apparently highly regarded among his Māori communities, as is evidenced by his nickname, "the Great White Chief." Māori custom demands that a chief never travel alone when visiting settlements and most of the tribes and congregations insisted that supporters travelled with Seamer on his journeys between Māori villages. Individuals would accompany the Reverend for several weeks until they felt that other people capable of giving him the necessary support had linked up with him. ${ }^{9}$ By 1924 , his success in this role saw him appointed to the newly combined role of General Superintendent of both the Home and Maori Mission Departments. Consequently, his duties were vastly increased and required further travel each year to provide support and leadership to the Methodist circuits nationwide. This role demanded great vision and focus to negotiate the different needs of both Pākehā and Māori people. ${ }^{10}$

Seamer brought to this role an active belief in the use of music to evangelize. Seamer saw music as a solution for attending to the needs of each group, particularly as both Māori and Pākehā congregations sang as a matter of course in Methodist services. One of the greatest problems confronting him on his visitations was how to key into Māori custom, as well as meet European expectations. He could not easily take his usual Māori retinue, who accompanied him on his travels, into Pākehā churches without some form of structure or explanation. ${ }^{11}$ After carefully reviewing the situation in 1924, Seamer engaged voluntary Māori helpers, for periods varying from 3 to 12 months, to assist him in both European and Māori Methodist mission work, leading them "up and down the land singing and speaking.","

Seamer named the group the Methodist Home Mission Party and they began performing on New Zealand stages from April 1924. Seamer had two separate parties in that first year with five members in the South Island tour (April to June), and five members in the North Island tour (June to December). The South Island group varied in ages and vocations, and included two Methodist Native Ministers, Reverend Eruera Te Tuhi of Kaipara and Reverend Te Aho-o-Te-Rangi Pihama from the Waikato, two young women, Ara Winiata of Hokianga and Ruihi Ruamoetahuna from the Taranaki region, and 10-year-old Rongo (Dolly) Kahui of Rahotu. ${ }^{13}$ One report on the party wrote that the members "possess sweet tuneful voices, and the weird waiatas, sacred poi and other action songs, solos, duets and quartets are a great delight. Both the men are natural orators and make very fine speeches. Rongo (Dolly) is a little girl of ten years and wins all the hearts as robed in a mat of kiwi feathers, she sings her solos." ${ }^{14}$ Audiences appreciated Seamer's inaugural deputation and the performers generated enjoyment through their mission work. Despite the pleasure in performing throughout the country, Rongo, Ara and Ruihi left the deputation group at the end of the South Island tour, probably due to the demanding nature of the tours. Meha Ngawhau and Teataarangi Waata replaced them for the North Island section of the tour. Another addition was Iroriana, who was a budding speaker with a good tenor voice. ${ }^{15}$

The number of members in the MHMP grew over time and by the 1930s the group consisted of 21 members at any one time. ${ }^{16}$ Seamer's method of recruitment was based on pre-existing connections with Māori groups and individuals when he began work as General Superintendent. His first priority in choosing a member was their true conversion to the Christian faith, and second, that they be ideally suited to performing constantly. Some of these early "companions" (as he always used to call them) were outstanding speakers, others were singers, while others were nominated by their people and accepted by Seamer because they in themselves seemed to be an illustration of the work the mission was doing. ${ }^{17}$ Seamer's companions were given the opportunity to perform and speak in Methodist churches and halls, providing room, he hoped, for growth of equality and understanding of Māori through 
education and evangelism. For the most part this work took place on a variety of religious stages; however, in later years this became more evenly distributed with performances to larger audiences on secular stages as well.

From the outset, the members of Seamer's choral group were from different Māori tribes, with individuals selected for their skills. Rivalry developed between various tribes as to which of them would have representation in the touring party. ${ }^{18}$ Seamer was careful to arrange that most tribes had representatives involved at some point, including Māori from as far as the Chatham Islands. While the majority of the early members were North Island based, by 1927 South Island Māori were also represented. Rangimarie Ellison, always known as Mori, became a member of Seamer's choir in that year. ${ }^{19}$ Mori became acquainted with Reverend Seamer through the Ōtākou Peninsula organist, Mrs Clark, who referred a letter sent by Seamer to her. He requested an Ōtākou regional representative for his touring party. "Naturally I was interested," wrote Mori, "and on asking my father his reply was, 'Please yourself, my dear'." ${ }^{\prime 20}$ Mori was thrilled to take up this role and travelled almost immediately to Te Aroha in the North Island where the choir were stationed. ${ }^{21}$ Her enjoyment in the group is evidenced in that Mori remained with the MHMP until 1938.

When the MHMP came together to perform, less emphasis was made of their tribal affiliations and more of their collective Māori culture and similarities. By selecting and creating a pan-tribal Māori choir, Seamer crossed boundaries not only on the stage, but also culturally off the stage. The religious stage therefore became a venue for tribal representatives to interact and influence each other in singing together, while simultaneously educating their audiences to a broader Māori outlook.

Seamer hoped the MHMP would bridge the gap between Māori and Pākehā church traditions and cultures. ${ }^{22}$ A report in the New Zealand Methodist Times (a national newsletter published weekly for the Methodist community) noted, "As Mr Seamer has only one hobby apart from his work, and that hobby is music, it was natural that the musical talents of the party should be developed, and at length, while the same representation principles were still observed, the fine inspirational, educational and musical programmes given by the party brought it into great prominence." ${ }^{, 3}$ Through music and performance, the MHMP portrayed a vibrant choral picture of cooperation, which aimed to bridge the gap between Māori and Pākehā congregations apparent within Methodist communities. ${ }^{24}$

The choir's extensive journey throughout New Zealand in 1924 foreshadows the annual tours that the MHMP made up to 1934. The choir began their eight-month 1924 tour of the Methodist circuits in the South Island at the Ōtākou region, working their way through South Otago, Central Otago, and then through Southland. At each region they visited small communities of Methodist parishioners, such as St Kilda, St Clair, and Abbotsford in the Dunedin area, as well as the major city churches. ${ }^{25}$ In Southland they performed in a variety of churches, town halls and schoolrooms, in communities such as Otautau, Nightcaps, Tuatapere, Colac Bay, Invercargill and Bluff. ${ }^{26}$ They spent up to two or three days in larger community churches during their tour and gave a morning, afternoon or evening performance while visiting smaller churches. After they had toured Southland, the group travelled up the East Coast. In Canterbury, they spent over a month dedicated to performing in the different towns. The group then carried on up the East Coast, performing to audiences in Blenheim and Picton before crossing by ferry to Wellington. ${ }^{27}$

An extensive North Island tour began in June and lasted until mid-December. A short tour of the Wellington region was followed in quick succession with performances in Wanganui, Taranaki and then the Waikato districts. A brief stop in the Auckland district preceded a longer tour of Northland, visiting towns such as Kaeo, Russell, Oruru and 
Mangonui. ${ }^{28}$ After a two-week rest at the end of July, the choir returned to Wellington in August, visiting numerous churches and communities in the surrounding district. ${ }^{29}$ For example, on 16 August 1924 the choir travelled to the Lower Hutt Methodist Circuit, to celebrate the Home Mission Anniversary Meeting at Taita Church. In a report to the New Zealand Methodist Times (NZMT), Mr Mitchell wrote:

The new Maori party, under Seamer, which has just visited Feilding, were greeted on Sunday and Monday with an over-crowded Church, every available inch of square space being occupied ... It is safe to say that never in the history of this circuit has there been such an inspirational, educational or more successful Home Mission Anniversary. It was a happy thought that brought the Maori Party into being and the opportunity of hearing the case for Home and Maori Missions put by the Superintendent and his helpers [was] highly appreciated. ${ }^{30}$

A tour of the East Coast, including the Hawkes Bay region, took place before the party headed back across to the West Coast where they spent time in Wanganui. ${ }^{31}$ From October to mid-November, the MHMP made an extensive tour of the Auckland district. ${ }^{32}$ The MHMP's penultimate tour was a short visit to Tauranga, in the Bay of Plenty. ${ }^{33}$ In December the choir finished with a week performing and visiting the Rātana Pā, just out of Wanganui, where Seamer had forged strong links with Tahupotiki Wiremu Rātana (1873-1939), the Māori prophet and founder of the Rātana Church. ${ }^{34}$

An important consequence of the Māori deputations was to bring young Māori members, many for the first time in their life, into European homes. The choir members were usually billeted with local families in each circuit, which brought them into close contact with residents of the communities they visited. In sharing food and hosting the members as guests, people who did not typically interact with Māori were exposed to that culture. ${ }^{35}$ For the most part the choir members found billeting to be a rewarding and enjoyable experience, with many friends made along the way. There was "the odd occasion that we patiently awaited the sound of Huddy's horn"- presumably, not all hosts were affable or perhaps understanding. ${ }^{36}$ On stage and off, the MHMP created a space for Māori to enter not only Pākehā churches but also homes, and, as one commentator wrote, the choirs "were a mutual blessing in removing many hurtful stereotypes in the minds of both peoples.",37

While assisting in educating audiences and communities throughout New Zealand, the MHMP also served a financial purpose, answering Seamer's need to help the Circuits reach their annual targets for monetary contributions towards the Home Mission Fund. ${ }^{38}$ One of the Māori elders would ask for donations during an interval in their performance. ${ }^{39}$ First they would speak in Māori, which would be translated by Reverend Seamer or a senior choir member. They would ask the audience to donate whatever they could to the Home Mission Fund in order to continue the progress already being made among Māori. A monetary donation was required for entry to most performances, particularly in the secular halls. By fundraising in this manner, the choir assisted each circuit in reaching its target contribution for the Home and Maori Mission Departments.

\section{Repertoire of the Methodist Home Mission Party}

The repertoire performed by the Methodist Home Mission Party provides insights into their appeal during the 1920s and 1930s. Live performance was welcomed in communities where music acted as a social vehicle for audiences to actively listen together in halls and at church. While radios and phonographs were being introduced in some New Zealand homes, the majority of families could not afford such technology, and thus live performance remained 
the main form of entertainment. The MHMP's unique combination of religious music, Māori repertoire, popular culture music and Western classical music held wide appeal. An investigation of the MHMP's repertoire reveals the cross-cultural encounters at play in the musical traditions in New Zealand.

\section{Religious Repertoire}

Music was one of the touchstones of most Christian denominations, whether it was the metrical psalms of Presbyterians, the Gregorian chant of Catholics, the hymnody of Luther and the Wesleys, or the open-air bands of the Salvation Army. "All human societies use music in the course of religious worship," writes ethnomusicologist Bruno Nettl. "It has been adopted everywhere to unify cultures, to confront other cultures, and to communicate with the supernatural." 41 For most denominations religious music was part of many New Zealanders' experience of worship. Worshippers sang in church choirs, during church services and at the close of sermons. In some denominations music instruction was nurtured through local church choirs and opportunities for leadership came in the form of choir directorship and leading congregations in hymn singing. ${ }^{42}$ Organ music, piano and instrumental music also characterized certain denominational services. Regardless of which denomination New Zealanders adhered to, the performance of music was inevitably a major part of people's religious experience. ${ }^{43}$

The MHMP typically performed in church services to provide entertainment and accompaniment as they travelled with Seamer on his annual visitations. Seamer encouraged all to attend, not just Methodists, and consequently large audiences would turn up for their performances. The religious repertoire performed by the choir was usually taken from an edition of The Methodist Hymn Book - most likely the combined prayer book and hymnal of 1927, The Methodist Church: Ko te Pukapuka o nga Inoi me era atu Tikanga a te Hahi Metoriti. ${ }^{44}$ The MHMP regularly performed the Doxology and the Lord's Prayer, both prayers chanted by congregations at the beginning and end of a sermon (and not only in Methodism). They also performed psalms such as $O$ Heavenly King (12) and $O$ God of Bethel (95). ${ }^{45}$ Hymns included Lord of all being (23), and Jesus, the First and Last (121). ${ }^{46}$ One reporter noted in 1931 that the choir's chanting of hymns was when "the Maoris [the choir members] seem at home, and the harmonies and the spirit in which it is done, is indeed stirring to the listener." $" 47$

While hymn and psalm singing was commonplace throughout Methodist New Zealand, so too was the development of a purely Māori experience of Christian hymnody. As some Māori embraced Christianity, this belief system was synthesized into indigenous culture. Ethnomusicologist Amy Stillman wrote about the process of Tahitian indigenous conversion to Protestantism that in particular, the belief system was "synthesised in fundamental ways, including the absorption of English hymn repertory and choral performance practice," and consequentially musical materials were reformulated according to indigenous musical practices. ${ }^{48}$ An emergent indigenized Christian musical idiom (with predominantly Protestant origins) was apparent in New Zealand in the early twentieth century. The MHMP adapted Christian music by altering the language into Māori, or by replacing the hymn tune with a traditional Māori one and retaining the poem. For example, one reviewer wrote that the MHMP performed an English hymn "in the native tongue." They went on to say that the hymn was "one of the first known to the race," and when interpreted, was Jesus, Son of Peace. ${ }^{49}$ At other times, the MHMP performed already adapted tunes. The hymn E Ihu, e te Kingi nui was adapted as early as 1848 to a British tune. At other times they performed a hymn written by a Māori chief in his own scale, and also a lively version of 
Abide with $M e{ }^{50}$ Such cross-cultural music, be it Methodist, Anglican or other, came to be accepted as indigenous. ${ }^{51}$

\section{Māori Cultural Performance}

While many Māori may have experienced religious hymnody in a variety of ways, European New Zealanders relied on travelling performing groups like the MHMP to bring not only live entertainment but also Māori culture to them. A 1925 programme for the MHMP drew attention to their cultural focus, noting that the concert "includes a number of items peculiar to the Native Race, including waiatas, pois, and Maori songs." 52 Typical rural New Zealand communities relished live performances, especially from travelling groups, but such overt displays of Māori culture were neither widespread at the time, nor typically conveyed through Western performance format and staging. In a number of centres throughout New Zealand, Pākehā and Māori did not interact on a daily basis (and sometimes not at all). An article in the NZMT commented: "Although travel is always recognised as one of the most important forms of education, it is difficult for Europeans to realise what a great boon for travelling and contact with European Christians in their homes and Churches is to our young Maori people. In their own settlements, unfortunately, they seldom have much contact with the better type of Europeans." 53

The lack of interaction between Māori and Pākehā appears to have triggered a Māori performance market in New Zealand. The MHMP was part of a small industry of semiprofessional Māori performers, revealing yet another aspect of the performance culture in the 1920s and 1930s. ${ }^{54}$ Māori groups found that value was attached to their performances for European audiences, which could therefore assist them to achieve religious, political or economic objectives. ${ }^{55}$ A minor tradition of touring religious Maori choirs was established near the turn of the twentieth century. For example, in 1908 the Rotorua Maori Mission Entertainers (RMME) performed throughout the Rotorua district, performing haka, poi, popular European tunes set to Māori lyrics, and American plantation songs. They also performed popular New Zealand songs, including Home, Little Maori Home and The Old Folks at Home. ${ }^{56}$

Similarly, the charismatic and powerful leader of the Waikato, Te Puea Herangi (1884-1952), established a travelling Māori choir, Te Pou o Mangatawhiri (TPM), in 1922. Te Puea was inspired to establish the touring party after she saw a Pacific Island group performing at Turangawaewae; she also saw it as a way to raise funds for the building of the meetinghouse Mahinarangi at Turangawaewae. ${ }^{57}$ TPM was a troupe of 44 performers whose initial concerts were given at Ngaruawahia and Tuakau in December 1922. In 1923 TPM undertook its first large tour, with the members walking vast distances around the North Island, performing in the Waikato, Auckland, the Kaipara District and Northland until, reportedly, the soles of their shoes were worn off. ${ }^{58}$

While other Māori groups performed for similar ends and there were contemporaneous religious groups, the MHMP was unique for several reasons. Some have praised Seamer's Methodist group for their adaptability. "In the Waikato," Donna Awatere commented, "the Methodists were especially successful because they did not attempt to reform Maori values, but were prepared to adapt church ritual to suit Maori tastes."59 Their adaptation is perhaps exemplified by their digression from an entirely religious repertoire to the inclusion of Māori culture. In the opening act of most of their performances, the members typically enacted traditional musical and cultural rituals such as the pōwhiri. ${ }^{60}$ The pōwhiri gave audiences a glimpse of traditional Māori life and meant they could engage with Māori tradition and be part of the ceremony, even only as spectators. The ritual subtly changed the 
balance between the audience and the performers. Both were locked in a process of interaction: the performers gave their hosts a presentation of their culture; audiences took with them education, entertainment and a better understanding of Maori culture.

The MHMP also typically performed waiata, or songs composed by Māori, throughout their concerts and mission meetings. Most waiata are sung to narrate a story of love, farewell, heartbreak and many other emotions. There are 34 distinguishable types of waiata, as defined by Mervyn McLean, each representing a different emotion or event. ${ }^{61}$ The MHMP performed much-loved contemporary waiata such as Te Akoako to Rangi, Hine $e$ Hine, Ka Taka Mai Awhi Mai, and Aue e Te Iwi. A comparatively contemporary waiata the choir performed was E Te Arawa Tirohia Ra, published in the New Zealand Pictorial News on 1 September $1928 .^{62}$ Another waiata the MHMP performed was E Pari Ra, which has a long history of adaptation by performers. ${ }^{63}$ The different meanings given to this one song exemplify the dynamic and changeable nature of waiata, and also the ways that Maori songs can be reinvented in each performance. In performing these songs, the MHMP simultaneously popularized them, while conveying a sense of normality to them on a variety of New Zealand stages.

The native poi dances that the MHMP performed were considered an intriguing spectacle. ${ }^{64}$ The poi is typically accompanied either by a rhythmic chant (an adapted version of a waiata) or to a Western-style tune in $2 / 4,3 / 4$, or $4 / 4$ time (common times in Western music genres). ${ }^{65}$ MHMP women interchanged between short and long poi action songs and dances for their audiences during their performances. ${ }^{66}$ The MHMP included a greater number of poi dances in their repertoire by the 1930s: for example, "six different poi dances were given" at one performance in Southland in 1932. ${ }^{67}$ The choir sometimes performed a seated canoe display called Uia Mai Koia ${ }^{68}$ The difficult timing and simulation of the sounds of waves hitting an imaginary canoe by the rhythmic clacking together of poi balls entranced audiences nationwide. ${ }^{69}$

The MHMP typically used haka to end their performances in a climactic fashion. The group usually performed haka that were particularly well known in New Zealand, such as Pakia Kia Rite and Ka Mate.$^{70}$ As most accounts of the choir's performances do not detail the effects that the haka had on audiences, we must rely on some general characteristics of haka to understand what audiences were likely to have witnessed. The use of foot stamping, body percussion, including thigh slapping and chest beating, quivering or trembling the hands (kakapa), the simultaneity of movement, and precision of time keeping marked the haka. ${ }^{71}$ Just as the poi is symbolic of female Māori culture, the haka, the war dance of Māori men, was thought to inspire courage in men $^{72}$ while women supported from behind the line of men. The haka represented more than any other form of dance the cultural manifestation of Māori as a fearsome warrior, a dominant image in the mind of Pākehā. ${ }^{73}$

Over the course of an evening, the MHMP interspersed music making with narrations of Maori history and tradition stemming from the colonization period in the nineteenth century. They did this by dividing the programme into two halves called the "Maori of Yesterday" and the "Maori of Today." Stories would be spoken in Māori with either Seamer or another senior choir member translating the narration into English. Such presentations were performances in themselves, with the intonation and meaning of the words imparting a sense of collective history for audiences. The story of the Māori race would be accompanied by the performances of waiata, haka and poi dances to demonstrate travels across the sea, and the choir sometimes transformed the stage into a village setting to depict traditional Māori life. 
The popularity and success of Seamer's musical group in New Zealand between 1924 and 1934 suggests the vibrancy of their performance culture. ${ }^{74}$ By using music and the stage as an active arena to interact with their audiences, they demonstrated their desire to educate New Zealanders more broadly about Māori culture. The mission party travelled throughout the country bringing their stories and repertoire to both small and large townships alike, entering the homes of those they were billeted with, and bringing new music and ideas into those communities.

\section{Popular and Western Music Repertoire}

The "Maori of Today" portion of the Methodist Home Mission Party's concerts typically demonstrated a varied and creative repertoire, which included popular music, Western classical genres and instrumental music, patriotic songs and Negro spirituals. They regularly performed famous English songs such as Annie Laurie and Danny Boy, much to the delight of their audiences in most communities. ${ }^{75}$ Simple Simon, a popular eighteenth-century English rhyme, was another English contemporary song either in Māori or in English. Other English tunes were performed in different languages and musical forms for comedic effect. Sometimes the choir sang in English the song Our Fathers Crossed the Ocean, to the tune of the German song Fahr' wohl, mein teures Lieb. ${ }^{76}$ English, Scottish, Welsh and French songs were sung in Māori, such as the Marseillaise. Much amusement was created when the choir performed a eulogy to Australian audiences in Māori to the tune of Three Blind Mice. ${ }^{77}$ Musical creativity and surprising musical effects were part of the choir's performances, which created interest for audiences. Such musical play indicates that cross-cultural engagements took place in popular repertoire as well as religious repertoire.

Western classical music, which consists of operatic, instrumental, ballad and air traditions, was part of the MHMP's repertoire. Diversity characterized the Western classical music scene in New Zealand. Many European New Zealanders enjoyed, were sometimes employed in, and performed in these classical genres, and an increasing number of Māori performed classical and operatic genres. Some Māori made a name on the international stage in the late nineteenth and early twentieth centuries, such as Fanny Howie ${ }^{78}$ and Eva Skerrett. $^{79}$

The fact that some MHMP members regularly performed in the Western classical style set them apart from other groups. A number of the choir members were classically trained and the MHMP was renowned for having singers of repute, including baritone Inia Te Wiata, who went on to forge a long and successful operatic career at Covent Garden in the 1950s and 1960s. Te Wiata joined Seamer's choir in 1932 and remained with them until the end of 1935, when he left to pursue traditional Māori carving training at Ngaruawahia. ${ }^{80}$ Similarly, long-serving member Airini Grennell, often referred to in the media as "the Chatham Islands Nightingale," was considered by many as the leading soprano of the choir. Grennell gave beautiful renditions of Tosti's Goodbye, Dudley Buck's Fear ye not, O Israel and Charles Gounod's aria $O$ Lord, Thy Redeemer. She was reportedly recalled to perform four or five times in an evening. ${ }^{81}$ Grennell had classical training, held a Diploma of Licentiateship for musicianship and was also an accomplished pianist. ${ }^{82}$ In performing classical music stylistically and competently, Māori performers like Grennell and Te Wiata challenged expectations of how traditional Māori should sound, proving that some Māori could cross the boundaries between Western and indigenous musical styles. The MHMP also provided rural communities an opportunity to listen to music in the Western classical tradition, which was particularly significant for those areas with limited access to the relatively new technology of gramophones and radios. 
Instrumental performances were popular throughout New Zealand, with musicians visiting to great acclaim, and the MHMP included instrumental performance. ${ }^{83}$ Many photographs of the choir show members posed behind or holding musical instruments, including the ukulele, acoustic and steel guitars, and violins. One observer remarked, "The visitors proved to be expert players of the steel and Spanish guitars, all these numbers being accorded hearty applause." ${ }^{84}$ The use of ukulele and steel guitar indicates Hawai'ian musical influence, from where the ukulele originates. Such a variety of musical skill was also part of the whole experience created by the performers in the MHMP.

New Zealand performers, musicians, composers and communities actively sought to promote patriotism and be part of the wartime spirit both during and after the war. Such patriotism was audible in the proliferation of jingoistic songs and the large number of public concerts taking place throughout New Zealand. ${ }^{85}$ Among the dozens of songs published during this period were The Call of the Fernleaf, Good Old New Zealand, Sons of New Zealand and The New Zealand Marseillaise. The MHMP performed such patriotic songs to commemorate those who went to war, including The Soldier's Farewell, ${ }^{86}$ particularly during the Anzac ceremonies each year. ${ }^{87}$

Just as patriotic music diversified the music spectrum, the introduction of "black" (or African-American) performances introduced layers of racial complexity to the performance traditions in New Zealand. American performers directly introduced spiritual and plantation songs to New Zealand, the music staying long after the performers had gone. ${ }^{88}$ The MHMP and others, including Te Puea's troupe, increasingly performed Negro spirituals in the 1920s and 1930s. Unfortunately many of the written records do not note what these spirituals were, only that they performed "a Negro spiritual," a "piccaninny" or "a plantation song." ${ }^{89} \mathrm{We}$ might speculate that the MHMP performed popular contemporary songs such as "Ma Curly Headed Babby" or "The Piccaninnies." "Such songs had popular currency on the stage and were enjoyed by many New Zealanders, which is evidenced by the large sheet music collection of Negro spirituals in the Sheet Music Archive of New Zealand in Wellington.

The Methodist Home Mission Party made a lasting impact on New Zealand stages and emphasized cross-cultural engagement between Māori and Pākehā in the early twentieth century. Reverend Seamer might be thought of as a Methodist visionary, who brought to his challenging role as the General Superintendent of both Home and Maori Mission Departments an active belief in the use of music to evangelize both Māori and Pākehā. In using the stage as a vehicle for intersection, Seamer and the MHMP could craft their narrative of Māori, simultaneously enabling the dissemination of Māori culture to their audiences and enabling Māori tribal representatives to influence each other through performing together.

An investigation of the MHMP's repertoire reveals a diverse and ever-changing experience of music as live entertainment on the stage. The choir's religious repertoire marked its origins in Methodism. Its development reveals an emergent indigenized Christian musical idiom, and one that involved remaking music to create not only a uniquely Māori experience of religious repertoire, but also a hybridized one, with evidence of cross-cultural exchanges.

The MHMP's performance of traditional Māori music, including waiata, haka, and poi dances, enraptured audiences throughout the country. While other groups such as Te Puea Herangi's Te Pou o Mangatawhiri also performed Māori repertoire, the MHMP differed because of the sheer extent of their annual performances and the choir's longevity. The "Maori of Today" portion of the MHMP's concerts demonstrated the ability to deliver a varied repertoire. This included contemporary popular music, Western classical genres and instrumental music, with opera, light airs and other such genres. Māori performers like the 
MHMP challenged expectations of what Māori should sound like, suggesting that crosscultural musical engagement occurred in most musical genres in this period.

The New Zealand stage, be it in a church hall or in a town hall, allowed a variety of interactions with audiences. The MHMP constantly challenged expectations about Māori through not only their repertoire but also their narration and behaviour. They proved to be a popular group whose visits were eagerly anticipated by most communities, and over the years, as relationships were forged and cemented, their talent and sound became more familiar. In one sense, Seamer's vision for better racial relations was achieved through the MHMP's performances. The stage allowed an expression of Māori history and culture, and on that same stage, the Methodist Home Mission Party negotiated their identity as Māori performers, as a Christian choir and as representatives abroad of New Zealand.

\footnotetext{
${ }^{1}$ See James Clifford, "Cultural Theory and Museum Studies," in A Companion to Museum Studies, ed. Sharon McDonald (Oxford: Blackwell, 2006), 25.

${ }^{2}$ Clifford, "Cultural Theory and Museum Studies," 25.

3 The choir's extensive tours to Australia (1935 and 1937) and to Great Britain (1937-1938) will not be explored in this article. They are discussed at length in chapters 4 and 5, respectively, of my thesis, Michelle Willyams, Singing Faith: A History of the Waiata Maori Choir, 1924-1938 (MA thesis, University of Otago, 2012).

${ }^{4}$ Seamer's earlier missionary experiences exposed him to the musical performance traditions of the Salvation Army. As historian Henry Gariepy aptly put it, "music, the universal language of mankind, is also the lingua franca of the [Salvation] Army world. It bonds its multinational members in an effective proclamation of the gospel message and nurtures the spiritual life of its followers." Christianity in Action: The International History of the Salvation Army (Michigan: Wm. B. Eerdmans Publishing Co., 2009), 28.

${ }^{5}$ Seamer was sent to New Zealand in 1897 with a missionary agenda to work among Māori in Gisborne and Taranaki. During these years he forged close relationships with Māori and became fluent in the language. He resigned from the Salvation Army in 1901 when policy changes were carried out by the national administration. He joined the Methodist missionary movement and was officially ordained as a Methodist Minister in 1907. See Michael King, Te Puea, Auckland, 1977, and Hirini Kaa, "Nga hahi - Maori and Christian denominations Salvation Army," Te Ara - the Encyclopaedia of New Zealand, accessed February 1, 2012 http://www.TeAra.govt.nz/en/nga-hahi-maori-and-christian-denominations/6.

${ }^{6}$ The day-to-day running of each circuit was governed by a number of ministers and deaconesses.

${ }^{7}$ For further details, see George Laurenson, Te Hahi Weteriana: Three Half Centuries of the Methodist Maori Missions, 1822-1972 (The Wesley Historical Society of New Zealand, 1972).

${ }^{8}$ E. W. Hames, Coming of Age: The United Church, 1913-1972 (Auckland: Institute Press, 1975), 57-58.

9 “The Maori Party: A Brief Historical Sketch,” New Zealand Methodist Times, August 4, 1934, 4, and W. J. Kerrison, "Religious Notes," Courier Mail, August 24, 1935, 7.

${ }^{10}$ Laurenson, Te Hahi Weteriana, 221.

${ }^{11}$ Although there was no formal separation between Pākehā and Māori in churches throughout the country, it appears an informal separation occurred in many churches. Seamer found that "no line [was] ever drawn between the two races in workshops, in offices, in dancing hall, or football or cricket field. But often when they came to Church life the line was drawn, and in one district the use of the Sunday school was refused to Maori children." "Methodist Annual Conference," Otago Daily Times, February 27, 1923, 6; "Changing Duties and Changing Needs," New Zealand Methodist Times, August 4, 1934, 4.

12 "Changing Duties and Changing Needs," New Zealand Methodist Times, 4; Hames, Coming of Age, 59.

13 "Where Methodism Stands," New Zealand Methodist Times. April 12, 1924, 13; "Home Mission Anniversary Meeting Pamphlet," Personal Collection of Mori Pickering (April, c.1920s), Dunedin. These members are also listed in the Otago Witness, May 20, 1924, 49.

14 “Our Home Missions," New Zealand Methodist Times, April 12, 1924, 13.

15 "Our Home Missions," New Zealand Methodist Times, August 30, 1924, 3.

16 The number of members throughout the choir's 15 -year existence was well over 100 in total. For an incomplete list of the members in the MHMP refer to Willyams, 157-59.

17 “Changing Duties and Changing Needs," New Zealand Methodist Times, 4.

${ }^{18}$ Ibid.
} 
${ }^{19}$ Born in 1909 at Ōtākou, Mori belongs to Ngāi Tahu, the main South Island tribe, and to Te Atiawa of Taranaki. After attending the local primary school, she went to board at Te Wai Pounamu Maori Girls' School in Christchurch. Mori later married and became Mori Pickering: Ruth Fry, Out of the Silence: Methodist Women of Aotearoa, 1822-1985 (Christchurch: Methodist Publishing, 1987), 181.

${ }^{20}$ Memoirs of Mori Pickering, Private Collection, Dunedin.

${ }^{21}$ Mori Pickering, "Reminiscences on the Waiata Choir as related to Ruth Fry," Out of the Silence: Women's Stories, 9320 Methodist Women's Fellowship National Executive Records (Christchurch: Methodist Church of New Zealand Archives), 1.

22 "Changing Duties and Changing Needs," New Zealand Methodist Times, 4.

23 "The Musical Emphasis," New Zealand Methodist Times, August 4, 1934, 4.

${ }^{24}$ Seamer declared this particular goal as a "line of action" in his opening report as General Superintendent in 1924: "Lines of Action," New Zealand Methodist Times, April 12, 1924, 13.

${ }^{25}$ Advertisement for the Methodist Home Mission Party in Broad Bay, Dunedin, 1924, Moss Collection, Christchurch.

${ }^{26}$ New Zealand Methodist Times, April 12, 1924, 13; New Zealand Methodist Times, April 26, 1924, 12.

${ }^{27}$ New Zealand Methodist Times, May 10, 1924, 13; New Zealand Methodist Times, May 24, 1924, 3.

${ }^{28}$ New Zealand Methodist Times, June 21, 1924, 3.

${ }^{29}$ New Zealand Methodist Times, July 19, 1924, 3; New Zealand Methodist Times, August 2, 1924, 3; New Zealand Methodist Times, August 16, 1924, 3.

${ }^{30}$ A. Mitchell, New Zealand Methodist Times, August 30, 1924, 3.

${ }^{31}$ Ibid.; New Zealand Methodist Times, September 10, 1924, 3.

${ }^{32}$ New Zealand Methodist Times, October 11, 1924, 3; New Zealand Methodist Times, October 25, $1924,3$.

${ }^{33}$ New Zealand Methodist Times, November 8, 1924, 3.

${ }^{34}$ Rātana's following grew rapidly among Maori: New Zealand Methodist Times, December 6, 1924, 17. Rātana came from Methodist and Anglican roots and was a fervent Christian man, and because of this Methodist connection Seamer chose to adopt a "carefully considered policy of silence on theological differences" so as not to alienate the Rātana movement from mainstream Christianity. Throughout Rātana's lifetime Seamer maintained a close friendship, and his commitment to young people and their education resulted in the establishment of a school at Rātana Pā serviced by Methodist lay teachers and deaconesses. Rātana honoured Seamer by commemorating his name in the township of Ratana, and naming a street after him: Ruawai D. Rakena, "Seamer, Arthur John - Biography," from the Dictionary of New Zealand Biography, Te Ara - the Encyclopaedia of New Zealand, accessed February 1, 2011, http://www.TeAra.govt.nz/en/biographies/4s18/1.

${ }^{35}$ Laurenson, Te Hahi Weteriana, 225.

${ }^{36}$ Both quotes from Pickering, "Private Collection," 2. "Huddy" referred to the old nine-seater Hudson van that the MHMP travelled in throughout their tours around New Zealand. They would load all their instruments, luggage, staging and props, as well as the choir members into the van: Pickering, "Reminiscences on the Waiata Choir," 4.

${ }^{37}$ Laurenson, Te Hahi Weteriana, 225.

${ }^{38}$ Pickering, "Reminiscences on the Waiata Choir," 2.

${ }^{39}$ Ibid., 6.

40 Katherine Massam, "Christian Churches in Australia, New Zealand and the Pacific, 1914-1970," in The Cambridge History of Christianity: World Christianities, 1914-2000, ed. Hugh McLeod (Cambridge: Cambridge University Press, 2006), 260.

${ }^{41}$ Bruno Nettl, "The Function of Music," in The New Grove Dictionary of Music and Musicians, Vol. 17, eds. Stanley Sadie and John Tyrrell (London: Macmillan, 2001), 434-35.

42 John Mansfield Thomson, The Oxford History of New Zealand Music (Auckland: Oxford University Press, 1991), 104.

${ }^{43}$ Massam, "Christian Churches," 254.

${ }^{44}$ The Methodist Church Ko te Pukapuka o nga Inoi me era atu Tikanga a te Hahi Metoriti (Weteriana) nga Himene me nga Hakamareta me era atu Ritenga Hoki o te Hahi (Ranana: [Methodist Church], 1927). They may also have used Sir Frederick Bridge, ed., The Methodist Hymn-Book with Tunes (London: Novello and Co., 1901).

${ }^{45}$ See Bridge, ibid.

46 "Maori Choir," Hutt News, October 28, 1931, 2; "Maori Concert," Ellesmere Guardian, March 1, $1932,5$.

47 "Maori Choir," Hutt News, 2. 
${ }^{48}$ Amy Stillman, "Himene Tahiti: Ethnoscientific and Ethnohistorical Perspectives on Choral Singing and Protestant Hymnody in the Society Islands, French Polynesia" (PhD diss., Harvard University, 1991), 491.

${ }^{49}$ It is difficult to verify this report with measured evidence, but it does reveal insight into contemporary discourse about the choir and their repertoire: "Maori Concert," Ellesmere Guardian, March 1, 1932, 5.

50 "Maori Choir in Colourful Presentation," Advertiser, May 10, 1935, 22.

${ }^{51}$ Amy Stillman, "Prelude to a Comparative Investigation of Protestant Hymnody in Polynesia," Yearbook of Traditional Music 25 (1993), 98.

${ }^{52}$ Evening Post, August 20, 1925, 10.

53 "A Great Training Ground," New Zealand Methodist Times, August 4, 1934, 4.

${ }^{54}$ Thomson, Oxford History of New Zealand Music, 6.

${ }^{55}$ In 1923, the Rātana Church established a brass band and choir. The Church increasingly took a political dimension, using music to reinforce their agenda to "defend the basic human rights of Maori." During his world tour from April to December of 1924, Rātana took his brass band and choir to petition King George V and the British Parliament for a resolution of Māori land grievances. See Moana Raurete, "The Origins of the Rātana Movement," in Michael King, ed., Tihe Mauri Ora: Aspects of Maoritanga (Auckland: Methuen, 1978), 42-66, and David G. Hebert, "Music Transculturation and Identity in a Maori Brass Band Tradition," Alta Musica 26 (2008), 180.

${ }^{56}$ Similarly, the Mormon Church of Jesus Christ of Latter-Day Saints quickly formed a choral group after the establishment of its mission school in Hastings in 1913. Two years later the music department at the Maori Agricultural College (MAC) featured a band, a choir and a glee club. They toured through Manawatu, Taranaki, King Country, Bay of Plenty, Auckland and Northland.

${ }^{57}$ Lilicherie McGregor, "The Praxis of Postcolonial Intercultural Theatre in Aotearoa New Zealand" (PhD thesis, University of Canterbury, 2004), 60.

${ }^{58}$ King, Te Puea, 116. Another group shared what Thomson describes as "choral glory" when the Ohinemutu Rotorua Maori Choir was founded in the late 1920s. This group also provides an example of vocal transition from the melismatic waiata singing to Western choral techniques: Thomson, Oxford History of New Zealand Music, 3-4.

${ }^{59}$ Donna Awatere, Maori Sovereignty, Auckland, 1984, 84,

${ }^{60}$ One example was the description of a performance in Otautau Town Hall, Southland: Mori Pickering, "Reminiscences on the Waiata Choir as related to Ruth Fry," 5.

${ }^{61}$ McLean, Maori Music: A Bulletin for Schools (Wellington: School Publications, Department of Education, 1971), 110-11.

${ }^{62}$ Hemi Piripata (who went by the alias Jim Philpotts) arranged and composed this piece: John Archer, "Matangi," New Zealand Folk Song, accessed February 1, 2012, http://folksong.org.nz/index.html.

${ }^{63}$ A footnote in the musical score of Begg's Famous Maori Songs (1926) notes that a young Hawkes Bay chief composed the song in 1824. The story refers to the incident when Ngapuhi and Urewera warriors overran Titirangi Pā, and the chief's lover was carried off into slavery: Begg, Famous Maori Songs (Auckland: Charles Begg and Co., 1926). While this may be the origin for the song, another version, most likely adapted for the purpose, suggests that $E$ Pari Ra was composed by Pairaire Tomoana and dedicated to Whakatomo Ellison of Hastings, who was killed in France during World War I: McLean, Maori Music, 319. Furthermore, the song became synonymous with the efforts of the Maori soldiers at war but much later the Ngāti Kahungunu tribe used the song at the opening of Mahinarangi meeting house at Ngaruawahia in March 1929: Ngamoni Huata, The Rhythm and Life of Poi (Auckland: Harper Collins, 2000).

${ }^{64}$ The poi dance supposedly dates from pre-European times, but there are no references to it in early literature: Suzanne Youngerman, "Maori Dancing since the Eighteenth Century," Ethnomusicology 18, no. 1 (1974), 94.

${ }^{65}$ Ibid.

${ }^{66}$ Ethnomusicologist Alan Armstrong argues that the long poi (with a string about the length of an arm) was the original form, but because only girls of high birth were permitted to dance with it, the lower classes invented the short poi (about 22cm long): Alan Armstrong, Maori Games and Hakas (Wellington: A. H. and A. W. Reed, 1964), 83.

67 “Rev. Seamer's Maori Choir," Otautau Standard and Wallace County Chronicle, April 5, 1932, 2.

${ }^{68}$ The Famous Waiata Maori Choir, Kiwi Archive record, LP: Side 1 (A. H. and A. W. Reed, 1937).

${ }^{69}$ Youngerman, "Maori Dancing since the Eighteenth Century," 94.

${ }^{70}$ The Famous Waiata Maori Choir, Side 1.

${ }^{71}$ McLean, Maori Music, 57-60.

${ }^{72}$ Joel Samuel Polack, Manners and Customs of the New Zealanders, 2nd ed. (London: Madden, 1840), 2-4. 
73 Christopher Balme, "Staging Pan-Polynesian Identity at the New Zealand International Exhibition, Christchurch 1906-07," in Performing Aotearoa: New Zealand Theatre and Drama in an Age of Transition, eds. Marc Maufort and David O’Donnell (New York: Peter Lang, 2007), 33.

${ }^{74}$ For more information on the group's reception and tours in Australia and in Great Britain, see Willyams, Singing Faith.

75 "Maori Choir," Hutt News, 2; "Maori Concert," Ellesmere Guardian, March 1, 1932, 5.

76 "Maori Choir," Mercury, April 6, 1937, 7.

77 "Waiata Maori Choir," Courier Mail, September 26, 1935, 10.

${ }^{78}$ Howie (1868-1916) was a contralto better known under her stage name of Princess Te Rangi Pai. She gave her début performance in Liverpool in late 1901, and was highly praised by the critics: McLean, Maori Music, 317.

${ }^{79}$ Skerrett (1890-1947) was born on Stewart Island and brought up in Bluff, and began singing at an early age. Billed as "the Maori Nightingale," she too had a successful career in England performing classical music and Maori waiata: McLean, Maori Music, 324.

${ }^{80}$ Beryl Te Wiata, Most Happy Fella (London: A. H. and A. W. Reed, 1976).

${ }^{81}$ New Zealand Methodist Times, October 18, 1930, 3; "Soprano Singers the Star," Barrier Miner, June 7, 1935, 2; "Maoris Please Large Audience," Barrier Miner, June 8, 1935, 3.

${ }^{82}$ Grennell travelled to England when she was 18 to study music professionally: Airini Payne, "Grennell, Airini Nga Roimata - Biography," from the Dictionary of New Zealand Biography, Te Ara - the Encyclopaedia of New Zealand, accessed November 12, 2011, http://www.TeAra.govt.nz/en/biographies/5g20/1; "Local and general news," Camperdown Chronicle, June 15, 1935, 8.

${ }^{83}$ One such performer was the European violinist Yoyanovitch Bratza: Evening Post, July 5, 1924, 21.

84 "Rev. Seamer's Maori Choir," 2.

${ }^{85}$ Chris Bourke, Blue Smoke, (Auckland: Auckland University Press, 2010), 4.

86 "Maori Choir," Hutt News, 2.

87 “The Happy Maori," Ellesmere Guardian, April 18, 1933, 8; "Anzac Day Celebrations to be Broadcast," Advertiser, April 20, 1935, 7; “Anzac Day,” Gippsland Times, April 26, 1937, 1.

${ }^{88}$ Formed as early as 1874, the Fisk Jubilee Singers were an American concert group of American ex-slaves and the sons and daughters of slaves, who introduced spirituals to New Zealand, even managing to visit during World War I. This group spent a season at the Auckland Town Hall's concert chamber: Thomson, Oxford History of New Zealand Music, 134. The New Zealand Herald noted that they performed "coon songs that are almost classical, and operatic excerpts." The reviewer went on to write that the Fisk Jubilee Singers were "an entertainment that has seldom been surpassed": New Zealand Herald, June 12, 1918, 5, quoted in Bourke, Blue Smoke, 7.

89 "Maori Choir in Colourful Presentation," Advertiser, May 10, 1935, 22.

${ }^{90}$ The lyrics of "The Piccaninnies" refer to interracial relations: "We're the real Piccaninnies only found in Ohio, some folk think dat we are all black, but dat's not so, you look about and you will find out, we are all brown in Ohio": "The Piccaninnies" and George Clutsam's "Ma Curly Headed Babby" are both held in the Sheet Music Archive of New Zealand, Wellington. 